\title{
Analyzing plant nutrient uptake and utilization efficiencies: comparison between crops and approaches
}

\author{
M. Weih $(D)$ K. Hamnér ・ F. Pourazari
}

Received: 25 January 2018 / Accepted: 25 June 2018 /Published online: 5 July 2018

(C) The Author(s) 2018

\begin{abstract}
Background Various indices are applied to evaluate the nutrient (mostly nitrogen, $\mathrm{N}$ ) use efficiency of plants, but those indices have rarely been compared across different crops, and the co-limitation of growth by nutrients other than $\mathrm{N}$ is usually not considered.

Aims To conceptually and quantitatively compare the indices of a plant-level, a plant-soil-level and a fieldlevel (difference) method for the assessment of $\mathrm{N}$ use across a set of different annual and perennial crops; and to use some plant-level indices for exploring the colimitation of growth by nutrients other than $\mathrm{N}$ in wheat. Method Data sets from previously published studies on wheat (grain), maize (feed), potato (starch), grassland ley (feed) and Salix (bio-energy) field-grown in Sweden were re-analyzed.

Conclusions This study is first in conceptually and quantitatively comparing various popular $\mathrm{N}$ use indices across a wide range of annual and perennial crops; and also proposes a methodology for exploring the colimitation of growth by nutrients other than $\mathrm{N}$. When comparing the plant-level and plant-soil-level methods,
\end{abstract}

Responsible Editor: Ismail Cakmak.

Electronic supplementary material The online version of this article (https://doi.org/10.1007/s11104-018-3738-y) contains supplementary material, which is available to authorized users.

M. Weih $(\bowtie) \cdot$ F. Pourazari

Department of Crop Production Ecology, Swedish University of Agricultural Sciences, Box 7043, SE-750 07 Uppsala, Sweden e-mail: martin.weih@slu.se the indices relating crop yields to the amounts of plantinternal $\mathrm{N}$ were correlated, while the $\mathrm{N}$-uptake indices were not. Only few of the field-level (differencemethod) indices were correlated with indices of the two other methods.

Keywords Agricultural crops · Element stoichiometry · Nitrogen · Nutrient use efficiency · Phosphorus

List of most frequently used acronyms, according to (a) Moll et al. (1982) or (b) Weih et al. (2011)

\begin{tabular}{|c|c|}
\hline $\mathrm{UpE}$ & 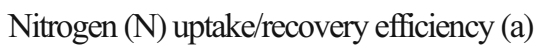 \\
\hline JUtE & ficiency (a) \\
\hline IUE & y (a) \\
\hline $\mathrm{U}_{\mathrm{N}}$, & $\begin{array}{l}\text { ipts } \mathrm{N} \text { for nitro } \\
\text { uptake efficien }\end{array}$ \\
\hline $\mathrm{E}_{\mathrm{\Lambda}}$ & Yield-specific nutrient $(\mathrm{N}$ or $\mathrm{P}$ ) efficiency $(\mathrm{b})$ \\
\hline $\mathrm{C}_{\mathrm{N}}$ & Yield nutrient $(\mathrm{N}$ or $\mathrm{P})$ concentration ( \\
\hline $\mathrm{AE}, \mathrm{NAF}$ & Nutrient $(\mathrm{N}$ or $\mathrm{P})$ accumulation \\
\hline & ficiency (b) \\
\hline
\end{tabular}

K. Hamnér

Department of Soil and Environment, Swedish University of Agricultural Sciences, Box 7014, SE-750 07 Uppsala, Sweden 


\section{Introduction}

The use of more nutrient-efficient crops is likely to play a pivotal role in increasing or maintaining crop yields in the future, especially in the light of current developments in the field of bio-economy which requires the ecologically sustainable production of food and biomass (Fageria et al. 2008; Spiertz and Ewert 2009). For example, crop nitrogen $(\mathrm{N})$ use efficiency has been proposed to be an indicator of progress towards a goal to end hunger, achieve food security, improve nutrition, reduce pollution, and promote sustainable agriculture (Norton and T. 2015). In contrast to the generally agreed importance of $\mathrm{N}$ use efficiency to achieve sustainability in agriculture, there are many different conceptions for the assessment of $\mathrm{N}$ use efficiency, and the co-limitation of growth by nutrients other than $\mathrm{N}$ is usually not considered. This review attempts to first disentangle the conceptual rationales of some popular methods for the assessment of $\mathrm{N}$ use efficiency, including the opportunities for considering nutrients other than $\mathrm{N}$; second quantitatively compare the different indices of some popular methods for the assessment of $\mathrm{N}$ uptake and use across a set of different annual and perennial crops; and third use one of the methods for exploring the colimitation of growth by nutrients other than $\mathrm{N}$ in wheat.

In general, nutrient use efficiency often considers the processes of carbon gain and loss in relation to the processes associated with the gain and loss of the major growth-limiting nutrients (Reich et al. 2014; Weih et al. 2017), and is often defined as mass balance between either the plant-internal or soil available nutrient amount, and the biomass output (e.g. whole-plant net biomass accumulation or harvested biomass yield). Nitrogen and phosphorus $(\mathrm{P})$ are considered the nutrients that most frequently limit plant growth, but other nutrient elements, the environmental conditions (e.g. temperature or light) and/or other resources (e.g. water) often co-limit growth. In the crop production context, nutrient use efficiency indices are often mass balance ratios between crop yield and total plant nutrient amount at final harvest and performed at field or plot scale. Although at similar scales, the indices used often integrate spatially complex aggregates of different constituents of soils and plants. An aggregate is here considered "a whole formed by combining several separate elements" (https://en. oxforddictionaries.com/definition/aggregate). Some of the published indices are highly aggregated constructs integrating biomass and nutrient pools from soils and plants grown in different environments, whereas others are less aggregated constructs integrating biomass and nutrient pools from soil and plants or only plants grown in a single environment (Fig. 1). For example, some of the higher aggregated nutrient use efficiency indices are calculated based on the differences between the corresponding values in fertilized and unfertilized plots, i.e., the difference methods such as agronomic efficiency, crop recovery efficiency, and physiological efficiency (Dobermann 2005); while other, less-aggregated approaches integrate information from the plant level only (Agren 1985; Hirose 2011; Weih et al. 2011). The less aggregated methods for assessment of nutrient uptake and use (i.e., plant-level methods) have well-defined system boundaries, while the higher aggregated methods (i.e., plant-soil-level and difference methods) have poorer defined system boundaries (Fig. 1). The distinction between aggregation levels, e.g., plant-based and plant-soilbased concepts is important for evaluating their sensitivity to the factors affecting the corresponding indices. For example, measures of soil nutrient availability and/or the releasing efficiency of nutrient fertilizer will not be reflected by the plant-level indices, which consider soil nutrient supply as an external factor affecting e.g. the plant-level nutrient uptake efficiency.

The terms nutrient use efficiency and nitrogen use efficiency, with the frequently used acronym NUE, have been used with reference to the properties of either individual plants or production systems with respect to the use of nutrients or N (Fageria and Baligar 2005; Reich et al. 2014; van Bueren et al. 2014). According to these and many other authors, there is no commonly agreed definition of NUE and, depending on the scale or target of the research, NUE refers to different identities. With a focus on individual plants, Hirose (2011) used the term NUE in the sense of the dry mass productivity per unit $\mathrm{N}$ taken up by the plant; whereas other authors called conceptually similar identities $\mathrm{N}$ productivity (Agren 1985) or N utilization efficiency (Moll et al. 1982). In contrast to Hirose (2011), several authors including Moll et al. (1982), Good et al. (2004) and $\mathrm{Xu}$ et al. (2012) defined the term NUE as the product of the previously mentioned $\mathrm{N}$ utilization efficiency and $\mathrm{N}$ uptake efficiency. Also the nutrient harvest index, i.e., the fraction of total accumulated nutrient that is allocated to the harvested product, has been discussed as a component of nutrient use efficiency in agronomic concepts defining NUE as the crop yield per unit of nutrient supply from soil and fertilizer (Barraclough et al. 2010; 


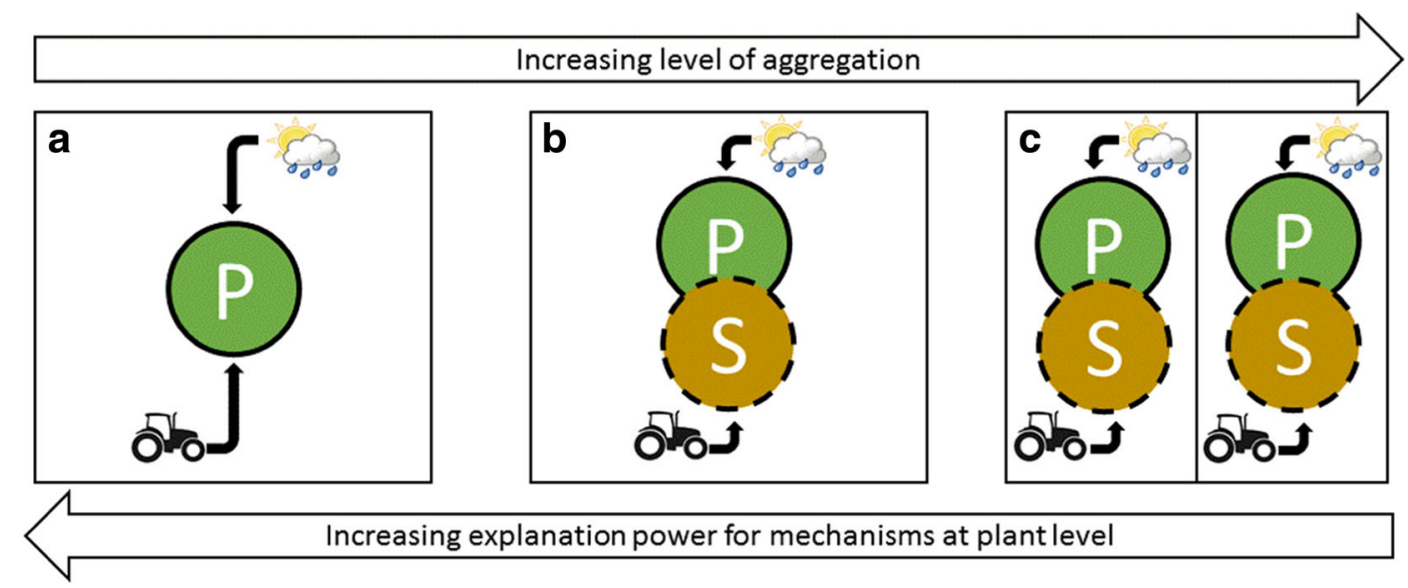

Fig. 1 Schematic comparison of the different conceptual frameworks used for the assessment of plant nutrient use efficiency from plant-level to field scale. The different concepts integrate spatially complex aggregates of different constituents of plants (acronym $\mathrm{P}$ in this figure) and in many cases soils (acronym S), as affected by environment (abiotic and biotic) and management; the solid lines indicate well defined system boundaries, whilst the broken lines indicate less well defined system boundaries. a Plant-level

Manschadi et al. 2014). However, nutrient harvest index reflects mostly nutrient allocation and crop management (e.g., straw cutting height; Barraclough et al. 2010), and is probably in many cases only marginally related to nutrient re-translocation. In addition, consideration of nutrient harvest index as a component of NUE appears meaningful only in crop-specific comparisons for those crops in which not all above ground biomass is harvested, and less meaningful for e.g. forage maize or grassland ley in which nutrient harvest index always would be 1 and not reflect nutrient re-translocation.

A general, as opposed to crop-specific concept for the assessment of critical components of nutrient use efficiency in annual and perennial crops was published by Weih et al. (2011), and since then the approach has been applied to various crops and contexts (Asplund et al. 2014, 2016; Pourazari 2016; Pourazari et al. 2018). Applied at different scale but in analogy to other conceptions derived from nutrient budgets (Leip et al. 2011; Oenema et al. 2003), Weih et al. (2011) originally defined nutrient (or N) use efficiency as a flow fraction in which the output is the nutrient yield of the crop and the input is the initial nutrient amount in the seed or other perennial plant parts. Instead of the farm or landscape scales in Leip et al. (2011) and Oenema et al. (2003), the system boundaries in Weih et al. (2011) are individual plants or crops observed during their entire life cycle (annuals) or representative parts of their life cycle conceptions in which soil nutrients (incl. from fertilizer) are treated as part of the environment (Agren 1985; Hirose 2011; Weih et al. 2011); (b) plant-soil-level methods integrating biomass and nutrient pools from soil and plants (Moll et al. 1982; Manschadi et al. 2014); (c) field-scale difference methods integrating biomass and nutrient pools from soils and plants grown in different environments (Dobermann 2005)

(perennials). Most indices are calculated in exactly the same way for annuals and perennials, except of the previous-year internal nutrient input that is represented by the seed nutrient pool in annuals and by the nutrient pool of other perennial plant parts in perennials (Weih et al. 2011). Since Weih et al. (2011) originally introduced their "nutrient use efficiency" or "NUE" concept, the applied terminology (especially NUE) has caused confusion. Following Pourazari et al. (2018), we propose here to adopt the term "nutrient accumulation efficiency", acronym NAE instead of NUE, to more accurately reflect the nature of this index and to more clearly separate the concept by Weih et al. (2011) from other uses and conceptions of NUE. According to Weih et al. (2011), nutrient uptake efficiency (U) is the ratio between the estimated mean nutrient amount in the plant during the entire growth period and the nutrient amount in the initial biomass (i.e., seeds or other perennial biomass); yield-specific nutrient efficiency (E) is the ratio between the harvested yield and the mean plant nutrient amount during the growth period; yield nutrient concentration $(\mathrm{C})$ is the ratio between the nutrient and biomass yield; and overall nutrient accumulation efficiency (i.e., nutrient use efficiency in the original publication) is the final nutrient yield divided by the nutrient amount in the initial (perennial) plant material, or $\mathrm{NAE}=\mathrm{U} \times \mathrm{E} \times \mathrm{C}$. A limitation of the concept by Weih et al. (2011) is the requirement of an accurate estimate of 
mean nutrient amounts during the growth period, which might be difficult to achieve especially in fast-growing plants, where multiple plant samplings are required within short time periods.

In contrast to the plant-soil-level and field-level (difference) methods, the nutrient uptake and accumulation efficiency indices by Weih et al. (2011) are element pool (or amount) ratios defined at the same individual-plant level as the element concentration ratios frequently used in ecological stoichiometry to study the balance of chemical elements in ecological interactions (Elser et al. 2010), ideal nutrient productivities (Agren 1988), and optimum element ratios (Knecht and Goransson 2004). This conceptual relatedness offers an opportunity to use some of the indices by Weih et al. (2011) for exploring the co-limitation of nutrients other than $\mathrm{N}$.

The aims of this review are to compare the different indices of a plant-level (Weih et al. 2011), a plant-soillevel (Moll et al. 1982) and a field-level (difference) method (Dobermann 2005) for the assessment of $\mathrm{N}$ uptake and use across a set of different annual and perennial crops; and to use the plant-level method for exploring the co-limitation of growth by nutrients other than $\mathrm{N}$ in wheat. To address the aims, we compiled data sets from some previously published investigations from field experiments with wheat (grain), maize (feed), potato (starch), grassland ley (feed) and Salix (bio-energy) in Sweden, and re-analyzed the data for the above aims.

\section{Material and methods}

Data source

Biomass, yield and nutrient data obtained from various field experiments carried out in Central and Southern Sweden were used for the analyses. The following annual and perennial crops were grown in the field experiments: Spring and winter wheat (grain), maize (feed), potato (starch tuber), mixed grassland ley (feed), and Salix (grown in short rotation forestry for shoot biomass used for energy). All data used in this investigation have been published previously: The data on wheat are from (Asplund et al. 2016; Hamner et al. 2017; Pourazari 2016; Weih et al. 2016); the data on maize, grassland ley and potato are from Pourazari (2016) and Pourazari et al. (2018); and the Salix data originate from Weih and Nordh (2005). In the original publications, the focus was frequently on cultivar differences. In contrast to most of the original publications, we here focused on the comparison between crops and the effects of environmental conditions on the different aspects of crop nutrient uptake and utilization, and we therefore used subsets of data for some representative (e.g. commercially used) cultivars to illustrate the variations between crops and environments. The cultivar choice is presented in the respective tables and figures. Information on the variation between different cultivars can be found in the original publications.

Assessment of nutrient uptake and utilization efficiency

Aspects of crop nutrient uptake and utilization efficiency were assessed by using the approaches by Moll et al. (1982) and Weih et al. (2011), and also, where applicable, the indices by Dobermann (2005). All calculations are specified in Table 1. The unit of assessment was always the (crop) plant or plant-soil-aggregate observed during one growth period, from the start to the end of significant plant nutrient and/or biomass accumulation. For feasibility reasons, only above-ground plant parts are considered in most cases, with the important exception of potato in which the below-ground tubers represent the harvested product and therefore were included in the assessments. Biomass accumulation in terms of harvested yield was recorded at one single occasion for most crops, with the important exception of grassland ley in which harvested biomass and nutrient amounts were recorded twice or three times during a single growth period to reflect the local agricultural practice. In general, the comparisons of annual and perennial plants are here made for single growth periods, which implies that the assessment period represents the entire life cycle in annual crops but only a (representative) part of the entire life cycle in perennial crops. Specifically, the nitrogen (N) use efficiency (NUE) and its components were calculated according to Moll et al. (1982); the NUE is here defined as the ratio of final yield (grain biomass in wheat, tuber biomass in potato, above ground biomass in grassland ley, and shoot biomass in Salix) to soil N per area, which was calculated as the sum of the $\mathrm{N}$ amount in the soil before fertilization and the applied $\mathrm{N}$ amount in the fertilizer. According to Moll et al. (1982), working with cereals, the two NUE components are (i) the $\mathrm{N}$ uptake/recovery efficiency (NUpE) calculated as the maximum above ground plant $\mathrm{N}$ pool (in cereals occurring at maturity) divided by the soil $\mathrm{N}$ per area, and thus as an expression of the $\mathrm{N}$ recovery efficiency from soil $\mathrm{N}$ resources (Burns 2006); 
and (ii) the $\mathrm{N}$ utilization efficiency (NUtE) calculated as the yield divided by the maximum plant $\mathrm{N}$ pool. We always used the maximum $\mathrm{N}$ pool during the growth period for the calculations of the NUpE and NUtE, although peak $\mathrm{N}$ pool did not occur at final harvest in all crops. For the same data, the whole-plant nutrient accumulation efficiency (NAE, called "NUE" in the original publication) and its components, e.g. $\mathrm{N}$ uptake efficiency $\left(\mathrm{U}_{\mathrm{N}}\right)$, yield specific $\mathrm{N}$ efficiency $\left(\mathrm{E}_{\mathrm{N}}\right)$ and yield $\mathrm{N}$ concentration $\left(\mathrm{C}_{\mathrm{N}}\right)$ for nitrogen, were computed according to Weih et al. (2011) for $\mathrm{N}$ and also other nutrient elements. According to Weih et al. (2011), N uptake efficiency $\left(\mathrm{U}_{\mathrm{N}}\right)$ is the ratio between the mean plant $\mathrm{N}$ amount during the growth period and the $\mathrm{N}$ amount in the perennial biomass prior to the start of the growth period. The $\mathrm{U}_{\mathrm{N}}$ is similar to the $\mathrm{N}$ uptake/recovery efficiency (NUpE) by Moll et al. (1982), but does not use the soil N content as the basis for the quantification of $\mathrm{N}$ uptake efficiency. For some nutrient elements other than N, optimal element uptake efficiencies were calculated in the same way as $U_{N}$ and using the element proportions in relation to $\mathrm{N}$ that have been suggested as the optimum nutrient ratios for herbaceous plants by Knecht and Goransson (2004); the optimal element uptake efficiencies were then compared with the observed element uptake efficiencies. Yield-specific $N$ efficiency $\left(E_{N}\right)$ is the ratio between the yield and the mean plant $\mathrm{N}$ amount during the entire growth period, and is thus similar to the NUtE by Moll et al. (1982), but calculation of $\mathrm{E}_{\mathrm{N}}$ does (in contrast to NUtE) not rely on the plant $\mathrm{N}$ pool at only one single developmental stage. The yield $\mathrm{N}$ concentration $\left(\mathrm{C}_{\mathrm{N}}\right)$ frequently represents the efficiency of $\mathrm{N}$ retranslocation into the harvested plant part in the sense that this is the efficiency of re-translocating $\mathrm{N}$ from annual to perennial plant parts; the latter are very often also the harvested products. The grassland ley was cut three times during the growing season, which is according to the commercial practice in the region (Pourazari 2016); biomass yield was accumulated across all three cuts, the peak N pool was used for calculating NUpE and NUtE, and the mean $\mathrm{N}$ pool for all three cuts was used to calculate $\mathrm{U}_{\mathrm{N}}$ and $\mathrm{E}_{\mathrm{N}}$. Where sufficient data was available, also the indices partial factor productivity (PP, yield per unit fertilized $\mathrm{N}$ ), agronomic efficiency (AE, yield gain per unit fertilized $\mathrm{N}$ ), crop recovery efficiency (CE, $\mathrm{N}$ yield gain per unit fertilized $\mathrm{N}$ ) and physiological efficiency (PE, yield gain per unit $\mathrm{N}$ yield gain) were calculated according to (Dobermann 2005) and the equations presented in Table 1.
Statistical analysis

To compare values of the various nutrient use indices across different crops, standard correlation and linear regression analysis was performed together with Principal Components Analysis (PCA), using SPSS version 22. In general, PCA is a technique that groups underlying variables that best differentiate a given set of data points. Here the SPSS version 22 procedure CATPCA was used to group the samples from various crops and field experiments according to yield and $\mathrm{N}$ use pattern, and relate the grouping to the supplementary variables harvested product (tuber in potato, grain in wheat, above-ground biomass in maize and grassland ley, and above-ground shoots in Salix); nutrient treatment (unfertilized or fertilized), and year (representing weather). Analysis variables (samples) were defined numeric (continuous), and supplementary variables were defined categorical.

Correlations across crops and crop-specific $\mathrm{N}$ uptake and utilization patterns

The various crops investigated here differed greatly in terms of life form (perennial, winter annual, summer annual), species, harvested product and management (fertilized and unfertilized, multiple harvests per year to harvest every third year). The crop yield varied by a factor of 4.5 across all crops, depending on the crop type (harvested product) and fertilization level (Table 2). The great variation in crop type, harvested product, management and yield offers an interesting material to compare differently aggregated approaches for the assessment of crop nutrient use. Some of the nutrient use indices used here were expected to be correlated, because they quantify similar processes, whereas others are conceptually distinct and therefore not expected to be correlated. The observed correlations (Supplementary Table S1) often confirmed the expected pattern. One of the components in both the Moll et al. (1982) and Weih et al. (2011) conceptions is the ratio yield output by plant-internal $\mathrm{N}$ amount, i.e., the $\mathrm{N}$ utilization efficiency (NUtE) and yield-specific $\mathrm{N}$ efficiency $\left(\mathrm{E}_{\mathrm{N}}\right)$, respectively. As the $\mathrm{NUtE}$ and $\mathrm{E}_{\mathrm{N}}$ represent similar processes, we expected them to be correlated across different crops. In our material, the NUtE and $\mathrm{E}_{\mathrm{N}}$ were strongly correlated (Pearson $r=0.962, p<0.001, n=11$ ). Both NUtE and $\mathrm{E}_{\mathrm{N}}$ thus can provide information about the relationship between plant carbon and nutrient economies, assumed 
Table 1 Overview of the various nutrient uptake and utilization indices used in this paper, together with their calculations

\begin{tabular}{|c|c|c|}
\hline Acronym, name & Calculation, unit & Reference \\
\hline $\begin{array}{l}\text { NUpE, Nitrogen uptake/recovery efficiency } \\
\text { NUtE, Nitrogen utilization efficiency }\end{array}$ & $\begin{array}{l}N_{f} /\left(N_{\text {soil }}+N_{\text {fert }}\right), \mathrm{g} \mathrm{g}^{-1} \\
Y / N_{f} ; \mathrm{g} \mathrm{g}^{-1}\end{array}$ & \multirow[t]{2}{*}{ Moll et al. (1982) } \\
\hline NUE, Nitrogen use efficiency & $Y /\left(N_{\text {soil }}+N_{\text {fert }}\right), \mathrm{g} \mathrm{g}^{-1}$ & \\
\hline $\begin{array}{l}U, U_{N}, U_{P}, \text { Nutrient (subscripts } N \text { for nitrogen or } P \text { for phosphorus) uptake efficiency } \\
E, E_{N}, E_{P}, \text { Yield-specific nutrient (nitrogen or phosphorus) efficiency }\end{array}$ & $\begin{array}{l}N^{\prime} / N_{p}, \mathrm{~g} \mathrm{~g}^{-1} \\
Y / N^{\prime}, \mathrm{g} \mathrm{g}^{-1}\end{array}$ & \multirow[t]{3}{*}{ Weih et al. (2011) } \\
\hline $\mathrm{C}, \mathrm{C}_{\mathrm{N}}, \mathrm{C}_{\mathrm{P}}$, Yield nutrient (nitrogen or phosphorus) concentration & $N_{y} / Y, \mathrm{~g} \mathrm{~g}^{-1}$ & \\
\hline NAE, $\mathrm{NAE}_{\mathrm{N}}, \mathrm{NAE}_{\mathrm{P}}$, Nutrient (nitrogen or phosphorus) accumulation efficiency & $N_{y} / N_{p}, \mathrm{~g} \mathrm{~g}^{-1}$ & \\
\hline $\begin{array}{l}\text { PP, Partial factor productivity } \\
\text { AE, Agronomic efficiency }\end{array}$ & $\begin{array}{l}Y / N_{f e r t}, \mathrm{~g} \mathrm{~g}^{-1} \\
\left.\left(Y_{F+}-Y_{F 0}\right) / N_{f e r t}\right), \mathrm{g} \mathrm{g}^{-1}\end{array}$ & \multirow[t]{3}{*}{$\begin{array}{l}\text { Dobermann } \\
\text { (2005) }\end{array}$} \\
\hline CE, Crop recovery efficiency & $\left.\left(N_{f F+}-N_{f F 0}\right) / N_{f e r t}\right), \mathrm{g} \mathrm{g}^{-1}$ & \\
\hline PE, Physiological efficiency & $\underset{\mathrm{g}^{-1}}{\left(Y_{F+}-Y_{F 0}\right) /\left(N_{f F+}-N_{f F 0}\right), \mathrm{g}}$ & \\
\hline
\end{tabular}

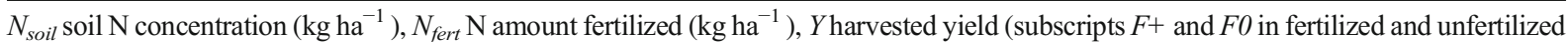
conditions, respectively) $\left(\mathrm{kg} \mathrm{ha}^{-1}\right), N_{p} \mathrm{~N}$ amount in perennial plant parts (e.g. seed in cereals, seed potato, winter shoots in Salix) (kg ha ${ }^{-1}$ ), $N_{i}$ initial plant $\mathrm{N}$ amount at start of the main growth period $\left(\mathrm{kg} \mathrm{ha}^{-1}\right), N_{f}$ final or maximum above ground plant $\mathrm{N}$ amount (or $\mathrm{N}$ yield) at the end of the main growth period (subscripts $F+$ and $F 0$ in fertilized and unfertilized conditions, respectively) $\left(\mathrm{kg} \mathrm{ha}^{-1}\right), N^{\prime}$ mean plant $\mathrm{N}$ amount during the growth period $\left(\mathrm{kg} \mathrm{ha}^{-1}\right), N_{y} \mathrm{~N}$ amount in the harvested yield $\left(\mathrm{kg} \mathrm{ha}^{-1}\right)$

that these indices integrate periods during which growth indeed is limited by low internal nutrient concentration (Rose et al. 2016; Santa-Maria et al. 2015). In contrast to NUtE vs. $\mathrm{E}_{\mathrm{N}}$, the $\mathrm{N}$ uptake/recovery efficiency (Moll et al. 1982), i.e., NUpE, reflects the ratio plant-internal by soil-available $\mathrm{N}$ amount, whereas the $\mathrm{N}$ uptake efficiency (Weih et al. 2011), i.e., $\mathrm{U}_{\mathrm{N}}$, is the ratio plantinternal $\mathrm{N}$ amount during the growth period by initial (from perennial plant parts e.g. seeds) $\mathrm{N}$ amount in the plant. The NUpE and $U_{N}$ thus represent conceptually distinct processes and were in our data not significantly correlated across crops (Pearson $r=-0.568, p=0.068$, $n=11$ ), which is expected. The potential $\mathrm{N}$ input from soil is a widely accepted basis for the assessment of $\mathrm{N}$ efficiency indices (cf. NUpE), but problematic because first, soil $\mathrm{N}$ assessments greatly depend on the methodology used (Carter and Gregorich 2008); second, the potential soil $\mathrm{N}$ pool is usually expressed at area (rather than volume) basis and thus has poorly defined system boundaries; and third, the $\mathrm{N}$ availability to plants also depends on the ability of the crop itself to compete with other consumption pathways for (mineralized) $\mathrm{N}$ (Osterholz et al. 2017). Instead of the soil N, the initial $\mathrm{N}$ amount in the perennial plant parts (e.g. seeds) is used in the calculation of $\mathrm{N}$ uptake efficiency $\left(\mathrm{U}_{\mathrm{N}}\right)$ (Weih et al. 2011). The consideration of the plant-internal $\mathrm{N}$ sources as the basis for $\mathrm{N}$ uptake indices (e.g., $\mathrm{U}_{\mathrm{N}}$ ) enables a lower aggregation level associated with higher explanation power for mechanisms at the plant level (Fig. 1), and is motivated by the documented influence of seed N content on seedling growth (Bulisani and Warner 1980; Evans and Bhatt 1977; Hanley et al. 2007; Naegle et al. 2005). In our data, the $\mathrm{N}$ amount in the perennial plant parts $\left(\mathrm{N}_{\mathrm{p}}\right)$, defining the plant or seed $\mathrm{N}$ pool prior to the start of any spring growth, varied by a factor of 96 among the crops (lowest in the smallseeded maize and highest in the perennial crops grassland ley and Salix) and was significantly correlated with yield and $\mathrm{N}$ yield (Pearson $r \geq 0.695, p \leq 0.018, n=11$; Supplementary Table S1). Given the wide range of $\mathrm{N}_{\mathrm{p}}$ values included here, such correlation is not surprising, but still indicates that the initial $\mathrm{N}$ present in the plant is functionally important for plant development and $\mathrm{N}$ accumulation later in the growing season. The plantinternal $\mathrm{N}$ amount during the growth period is differently defined in the two conceptual approaches used here (Moll et al. 1982; Weih et al. 2011). For the calculation of NUpE and NUtE (Moll et al. 1982), the final or peak $\mathrm{N}$ pool $\left(\mathrm{N}_{\mathrm{f}}\right)$ is used, whilst the mean $\mathrm{N}$ pool $\left(\mathrm{N}^{\prime}\right)$ is applied for calculating $U_{N}$ and $E_{N}$ (Weih et al. 2011). As expected, both the final and mean $\mathrm{N}$ pools significantly increased with the soil $\mathrm{N}$ supply (sum of $\mathrm{N}_{\text {soil }}$ and $\mathrm{N}_{\text {fert }}$, Table 2; Pearson $r \geq 0.605, p \leq 0.048, n=11$ ). However, whilst the $U_{N}$ and NAE (Weih et al. 2011) 


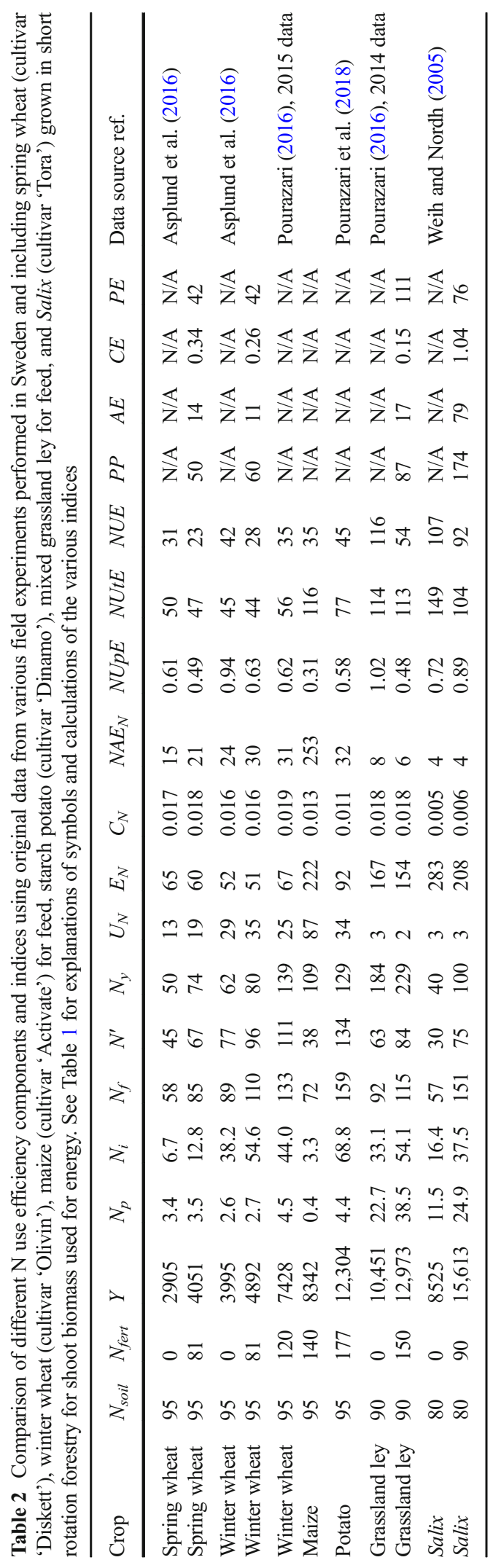


were uncorrelated with soil N supply (Supplementary Table S1), the NUpE (Moll et al. 1982) decreased with increased soil $\mathrm{N}$ supply (Pearson $r=-0.664, p=0.026$, $n=11$ ). The $\mathrm{U}_{\mathrm{N}}$ and NAE (Weih et al. 2011) quantify the plant-internal $\mathrm{N}$ uptake in relation to the initial $\mathrm{N}$ uptake, and are therefore less sensitive to the soil $\mathrm{N}$ supply. The NUpE (Moll et al. 1982) expresses the $\mathrm{N}$ recovery efficiency from soil $\mathrm{N}$ resources (Burns 2006), and therefore is sensitive to the soil $\mathrm{N}$ supply and also the different methods of assessing soil $\mathrm{N}$ availability as previously discussed. A general trend of decreasing $\mathrm{N}$ uptake/recovery efficiency (NUpE) with increasing soil $\mathrm{N}$ supply was observed in our material (Table 2) and is in agreement with the trends reported for various crops (Barbieri et al. 2008; Gauer et al. 1992; Zebarth et al. 2004). Functionally, the causes for the decreased $\mathrm{N}$ uptake/recovery efficiency with increased soil $\mathrm{N}$ supply are complex and cannot be evaluated with the more aggregated NUpE identity, as the causes could be related to variation in plant processes (e.g. genotype differences in physiology) or soil processes (e.g. variation in soil physical or microbial properties). The difference methods such as agronomic efficiency, crop recovery efficiency, and physiological efficiency (Dobermann 2005) compare plant and soil nutrient pools from fertilized and unfertilized fields at a high aggregation level (Fig. 1), and the difference measures were in some cases correlated with indices by Moll et al. (1982) and Weih et al. (2011). For example, the partial factor productivity (PP) increased with the NUE (Pearson $r=0.985, p=$ $0.015, n=4)$, and higher yield or $\mathrm{N}$ yield gain per unit fertilized $\mathrm{N}$ (i.e., agronomic efficiency, AE; and crop recovery efficiency, CE) was associated with lower $\mathrm{C}_{\mathrm{N}}$ (Pearson $r \leq-0.971, p \leq 0.029, n=4$ ).

By comparing the various $\mathrm{N}$ use indices across crops, some crop specific $\mathrm{N}$ use patterns emerge. Compared to the annual crops, the perennial grassland ley and Salix were characterized by higher $\mathrm{N}_{\mathrm{p}}, \mathrm{E}_{\mathrm{N}}$ and NUtE, but lower $\mathrm{U}_{\mathrm{N}}$, the latter is caused mainly by the higher $\mathrm{N}$ amount in the perennial plant parts $\left(\mathrm{N}_{\mathrm{p}}\right.$, Table 2). Winter wheat accumulated greater $\mathrm{N}$ pools $\left(\mathrm{N}^{\prime}\right.$ and $\left.\mathrm{N}_{\mathrm{f}}\right)$ than spring wheat, which also was reflected by higher $\mathrm{U}_{\mathrm{N}}$ and NUpE, but slightly lower $\mathrm{E}_{\mathrm{N}}$ and NUtE. The maize (grown for feed) was characterized by high $\mathrm{N}$ uptake efficiency $\left(\mathrm{U}_{\mathrm{N}}\right)$, but not $\mathrm{N}$ uptake/recovery efficiency $(\mathrm{NUpE})$; along with high $\mathrm{E}_{\mathrm{N}}$ and NUtE. Potato achieved the highest yield and $\mathrm{N}$ pool $\left(\mathrm{N}_{\mathrm{f}}\right.$ and $\left.\mathrm{N}^{\prime}\right)$ of all annual crops, along with relatively high $\mathrm{E}_{\mathrm{N}}$ and NUtE values. The crop-specific $\mathrm{N}$ uptake and utilization patterns are reflected in the grouping of samples in Principal Components Analysis (PCA) when using crop yield and the $\mathrm{N}$ uptake and utilization indices $\mathrm{N}_{\mathrm{p}}, \mathrm{N}^{\prime}, \mathrm{U}_{\mathrm{N}}, \mathrm{E}_{\mathrm{N}}$ and $\mathrm{C}_{\mathrm{N}}$ (Weih et al. 2011) for the discrimination (Table 3, Fig. 2). The PCA dimension 1 was strongly correlated with the $\mathrm{E}_{\mathrm{N}}$ and yield, whilst the PCA dimension 2 mostly represented the $\mathrm{U}_{\mathrm{N}}$ and the PCA dimension 3 very much reflected the variation in the mean plant $\mathrm{N}$ pool $\left(\mathrm{N}^{\prime}\right)$. Accordingly, the increasing $\mathrm{E}_{\mathrm{N}}$ from wheat through potato to the perennials (grassland and Salix) is reflected by the PCA dimension 1; the maize is separated from the other crops in terms of high $\mathrm{U}_{\mathrm{N}}$ seen in the PCA dimension 2; and the PCA dimension 3 discriminates both the potato from the other crops, and between spring and winter wheat by means of the variation in mean $\mathrm{N}$ pool $\left(\mathrm{N}^{\prime}\right)$. The mean $\mathrm{N}$ pool $\left(\mathrm{N}^{\prime}\right)$, i.e. PCA dimension 3, was also the main discriminator between fertilized and unfertilized crops; whilst the $\mathrm{E}_{\mathrm{N}}$ and yield, i.e. PCA dimension 1 , strongly reflects also the type of the harvested product.

The analyses show that the NAE and its components (Weih et al. 2011) appear to reflect relevant aspects of plant-level $\mathrm{N}$ uptake and utilization in an agricultural context, especially when the indices integrate periods during which plant growth can be assumed to be limited by the nutrient in question (Santa-Maria et al. 2015); and that the combination of the indices can discriminate between crop-specific patterns of $\mathrm{N}$ uptake and utilization (e.g., Fig. 2). Accordingly, maize is here characterized as efficient in both $\mathrm{N}$ accumulation and utilization, the perennial crops are characterized mainly by a high efficiency in $\mathrm{N}$ utilization, and potato is an efficient $\mathrm{N}$ accumulator especially early in the growing season (thus allowing high mean $\mathrm{N}$ pool during the growth period). Winter wheat is grown from autumn to autumn and, due to its greater capacity to grow roots before the onset of the growing season, a better $\mathrm{N}$ accumulator than springsown wheat; whilst the latter tends to utilize its accumulated $\mathrm{N}$ resources more efficiently than winter wheat (Table 2).

For some of the crops data from two different nutrient fertilization treatments were available, and the fertilization response nicely illustrates the different conceptions behind the indices applied in this comparison: In spring and winter wheat, moderate nutrient fertilization resulted in increased $U_{N}$ and $\mathrm{NAE}_{\mathrm{N}}$ (Weih et al. 2011), whilst it decreased the $\mathrm{N}$ uptake/recovery efficiency in terms of NUpE (Moll et al. 1982) (Table 2). In the two perennial crops (grassland ley and Salix), the fertilization had no 
Table 3 Principal Components Analysis (PCA) results for various crops grown in different field experiments in Sweden. Correlations between the first three principal components (PCA dimensions 1, 2 and 3 ) and the original variables, according to PCA presented in Fig. 2; components are yield and various plant-level
$\mathrm{N}$ use indices $\left(N_{p}, N^{\prime}, U_{N}, E_{N}, C_{N}\right.$; see Table 1), and the supplementary variables are harvested product (tuber in potato, grain in wheat, above-ground biomass in maize and grassland ley, or above-ground shoots in Salix), nutrient treatment (unfertilized or fertilized), and year (representing weather)

\begin{tabular}{llll}
\hline PCA component & PCA dim. 1 & PCA dim. 2 & PCA dim. 3 \\
\hline$N_{p}$ & 0.679 & -0.510 & -0.312 \\
$N^{\prime}$ & -0.032 & -0.472 & 0.870 \\
$U_{N}$ & -0.194 & 0.838 & 0.256 \\
$E_{N}$ & 0.903 & 0.238 & -0.271 \\
$C_{N}$ & -0.718 & -0.318 & -0.237 \\
$Y$ & 0.835 & 0.060 & 0.436 \\
Harvested product* & 0.724 & 0.169 & -0.438 \\
Nutrient treatment* & 0.058 & -0.125 & -0.504 \\
Year* & -0.653 & -0.054 & 0.234 \\
\hline
\end{tabular}

*Supplemental categorical variables in PCA

strong effect on the $\mathrm{U}_{\mathrm{N}}$ and $\mathrm{NAE}_{\mathrm{N}}$, but decreased (grassland ley) or increased (Salix) the NUpE. In the grassland ley, the higher NUpE in the unfertilized conditions is probably caused by greater $\mathrm{N}$ fixation by the legumes that are important components in these grassland leys (Carlsson and Huss-Danell 2003). The greater N uptake/ recovery efficiency (sensu NUpE) in the fertilized compared to unfertilized Salix probably reflects the greater foraging capacity for soil nutrients of the perennial root system, which has been argued to result in a high resource use efficiency of perennial compared to annual crops (Tilman et al. 2002). In all crops investigated here, the yield per plant-internal $\mathrm{N}$ amount $\left(\mathrm{E}_{\mathrm{N}}\right.$ and $\mathrm{NUtE}$ ) responded similarly to increased nutrient fertilization in the two conceptions, i.e., generally negative fertilizer effects were observed on those identities (Table 2). A more detailed analysis of the responses to gradually increased nutrient fertilization in winter wheat showed that increasing $\mathrm{N}$ fertilization up to $240 \mathrm{~kg} \mathrm{~N}^{-1}$ resulted in consistently increasing $\mathrm{N}$ accumulation (i.e.,

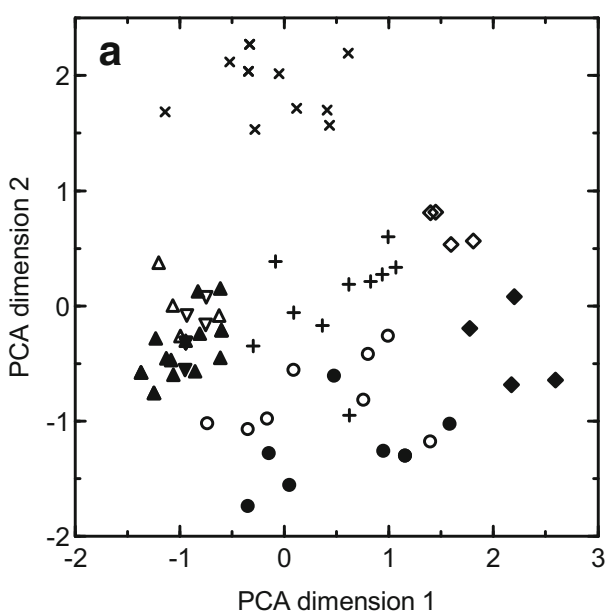

Fig. 2 Grouping of samples according to yield and $\mathrm{N}$ use pattern in Principal Components Analysis (PCA). Samples are replicates of yield and plant-level $\mathrm{N}$ use observations $\left(N_{p}, N^{\prime}, U_{N}, E_{N}, C_{N}\right.$; see Table 1) obtained from various field experiments in which different crops (i.e., winter and spring wheat, maize, potato, grassland ley, Salix) were grown with (closed symbols) and without fertilizer (open symbols) in Sweden during several years (1 year for spring

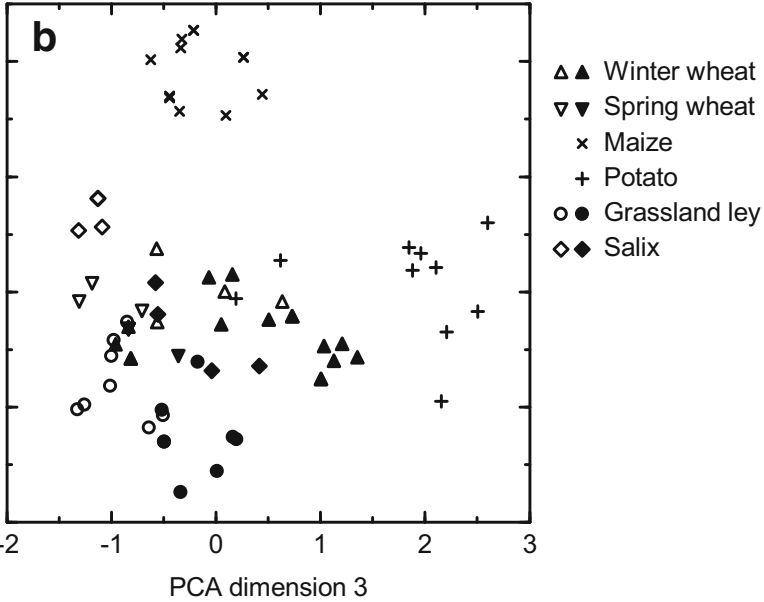

wheat, potato and Salix; three years for winter wheat, maize and ley). a PCA dimension 2 vs. PCA dimension 1 and (b) PCA dimension 2 vs. PCA dimension 3. Eigenvalues 2.53 for dimension 1 (explanatory power 42\%), 1.35 for dimension 2 (explanatory power $23 \%$ ), and 1.24 for dimension 3 (explanatory power $21 \%$ ). Data sources see references in Table 2 
$\mathrm{U}_{\mathrm{N}}$ and $\mathrm{NAE}_{\mathrm{N}}$ ) along with decreasing $\mathrm{E}_{\mathrm{N}}$ values, while grain $\mathrm{N}$ concentration $\left(\mathrm{C}_{\mathrm{N}}\right)$ was increased above $\mathrm{N}$ fertilization with $80 \mathrm{~kg} \mathrm{~N}^{-1}$ (Fig. 3). It is noteworthy that the highest $\mathrm{E}_{\mathrm{N}}$ was here achieved at the lowest grain yield (i.e., the N0 treatment in Fig. 3), implying that maximizing $\mathrm{N}$ utilization efficiency is not necessarily associated with higher yields. However, it is possible that plant growth at the high fertilization levels in this study was limited more by factors other than $\mathrm{N}$, which raises a caution of interpreting the observed $\mathrm{E}_{\mathrm{N}}$ values in terms of intrinsic $\mathrm{N}$ utilization efficiency (Santa-Maria et al. 2015). In contrast to the pattern for $\mathrm{N}$, the $\mathrm{P}$ uptake efficiency $\left(\mathrm{U}_{\mathrm{P}}\right)$ levelled off above $\mathrm{N}$ fertilization with $160 \mathrm{~kg} \mathrm{~N}^{-1}$, yield-specific $\mathrm{P}$ efficiency $\left(\mathrm{E}_{\mathrm{P}}\right)$ generally increased with $\mathrm{N}$ fertilization, and grain $\mathrm{P}$ concentration $\left(C_{P}\right)$ was highest in the unfertilized crop. The high $C_{P}$ in the unfertilized (N0) crop possibly indicates strong $\mathrm{N}$ limitation of grain yield by $N$. The increasing $E_{P}$ with decreasing $\mathrm{E}_{\mathrm{N}}$ (and increasing fertilizer supply) possibly could be an indicator that $\mathrm{P}$ increasingly co-limited growth and yield formation in these crops. Another consequence of the observed pattern is that the increase of the overall nutrient accumulation efficiency with fertilization was less pronounced for $\mathrm{P}$ (i.e., $\mathrm{NAE}_{\mathrm{P}}$ ) compared to $\mathrm{N}\left(\mathrm{NAE}_{\mathrm{N}}\right)$ (Fig. 3). The overall patterns were similar between the two locations investigated, although growth, yield and nutrient uptake levels differed between them.

\section{Co-limitation of growth by several nutrients}

Most literature on plant nutrient uptake and use considers only few nutrient elements, mainly $\mathrm{N}$ and sometimes also $\mathrm{P}$, although also other nutrients are important in co-limiting plant growth (Agren 1988; Reich et al. 2014). The nature of nutrient limitation has been previously explored with variable success by using critical nutrient ratios (Drenovsky and Richards 2004; Koerselman and Meuleman 1996), but also those approaches are usually restricted to the consideration of only few nutrients that usually were assessed only at single points in time. We use here the plant-level conception by Weih et al. (2011) to explore patterns of nutrient uptake and use across entire growth periods and for several nutrients, assuming that the plant growth rate is proportional to the nutrient content minus a given minimal concentration of the nutrient in minimum (Agren 1988). In a previous study, we had calculated element concentration ratios, i.e., the ratios of element concentrations observed at different time points, in winter wheat field-grown during two growing seasons (2013 and 2014) to explore the temporal trajectories of element concentration pattern during different developmental stages from sown to harvested seed (Weih et al. 2016). Based on the same data, we here calculated element uptake and accumulation efficiencies for eleven nutrient elements and plotted them against the corresponding element concentration ratios (Fig. 4a, b). Nutrient uptake efficiency $(\mathrm{U})$ is the ratio between the mean nutrient uptake during the growth period and the nutrient amount of the sown grain, and linearly correlated with the element concentration ratio between the flowering stage (vegetative biomass) and sown seed (Fig. 4a). Similarly, nutrient accumulation efficiency (NAE) is the harvested nutrient yield in grain per unit of nutrient in the sown grain, and a linear function of the element concentration ratio between harvested and sown seed; the slopes of the regression lines reflect grain yield which was twice as high in 2014 compared to 2013, due to different weather (Weih et al. 2016) (Fig. $4 \mathrm{~b})$. The positions of individual elements along the regression lines indicate the observed uptake relative to the other elements, and partly varied between the 2 years. For example, $\mathrm{P}, \mathrm{Mg}$ and $\mathrm{Na}$ showed similar concentration ratios but different NAE in the 2 years, whilst the opposite pattern was observed for Fe (Fig. $4 \mathrm{~b})$. This information could be interesting in the context of the driving forces behind nutrient accumulation (e.g. re-translocation in the grain-filling phase) and concentration patterns in wheat grain, but appears less relevant for evaluating nutrient accumulation during growth in relation to optimum nutrition throughout the entire growth period. The evaluation of nutrient accumulation in the vegetative crop in relation to optimum nutrition and growth limitation by nutrients is facilitated by combining the information from nutrient uptake efficiency (U) and element concentrations (cf. Fig. 4a) with predicted optimum element rations for plant growth. The actual observations of nutrient uptake efficiency assessed for different elements (called observed $U$ in Figs. 4 and 5) were here compared with the predicted values for the corresponding elements (called predicted $\mathrm{U})$. We predicted the optimal element uptake efficiencies using the published optimum N-to-nutrient ratios by Knecht and Goransson (2004) for herbaceous plants. Thus, we first calculated the optimum amounts of elements in seeds and vegetative plant (growing-season means) from the corresponding observed amounts of 
Fig. 3 Crop biomass at flowering (a) and grain yield (b); and plantlevel nutrient accumulation efficiency components $(\mathbf{c}-\mathbf{j})$ in winter wheat (cultivar 'Ellvis') grown during the 2014 growing season at two locations in Central Sweden (Falkenberg and Nybble near Örebro) at four $\mathrm{N}$ fertilizer levels $\left(0,80,160\right.$ and $240 \mathrm{~kg} \mathrm{~N} \mathrm{ha}^{-1}$, with addition of $\mathrm{P}, \mathrm{K}$ and $\mathrm{S}$ ). Terminology is according to Table 1 . Error bars indicate $\pm 1 \mathrm{SD}$. $U, E$ and $N A E$ were assessed for $\mathrm{N}$ and $\mathrm{P}$, and the data is calculated by dividing the mean from four replicates sampled at one occasion by the mean from four replicates sampled at another occasion, a procedure not allowing the calculation of simple variability measures. Data source and detailed information about the growth conditions: Hamner et al. (2017)
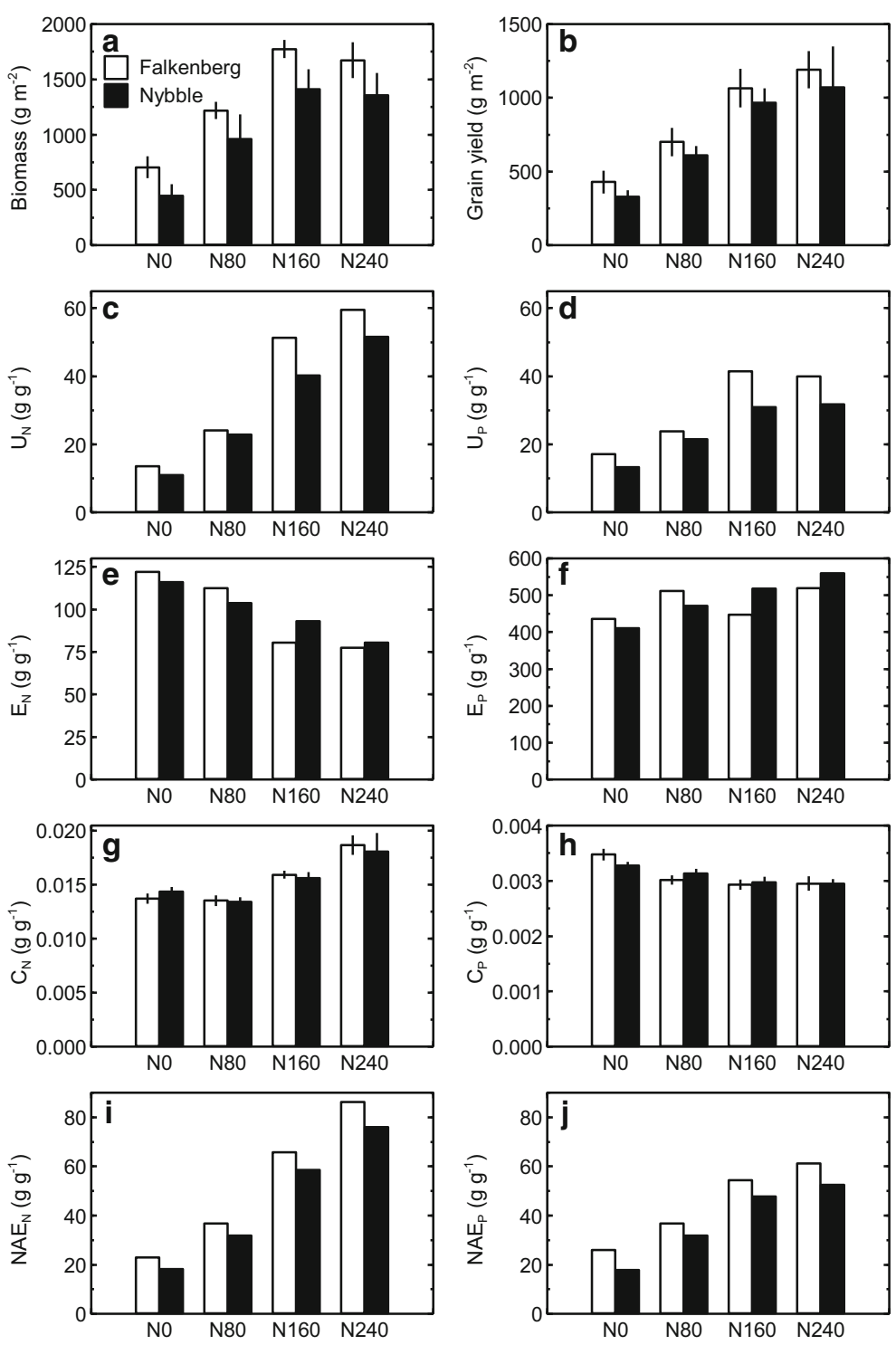

plant $\mathrm{N}$; and computed then the predicted $\mathrm{U}$ as the ratio of the two (i.e., predicted vegetative plant mean element content by seed element content). For the wheat data by Weih et al. (2016), the observed nutrient uptake efficiencies for $\mathrm{Ca}$ and $\mathrm{K}$ were clearly higher than the predicted optimum uptake for both years, whilst the observed values for $\mathrm{P}$ and $\mathrm{Mg}$ were slightly lower than the predicted optimum values (Fig. 4c, d), although this field had received some $\mathrm{P}$ and $\mathrm{K}$ at sowing (Weih et al. 2016). Similar calculations were performed for the wheat data from the $\mathrm{N}$ fertilization study by Hamner et al. (2017), in which the crop also received some $P$ and $\mathrm{K}$ at sowing in the two sites considered here (Nybble and Falkenberg). In both fields, the observed P uptake efficiency was higher or close to the predicted optimum uptake efficiency at all $\mathrm{N}$ fertilization levels, whilst the observed Mg uptake efficiencies increasingly fell below the optimum values at the two highest $\mathrm{N}$ fertilization levels (i.e., 160 and $240 \mathrm{~kg} \mathrm{~N} \mathrm{ha}^{-1}$ ) (Fig. 5). It is therefore possible that $\mathrm{Mg}$ was significantly colimiting wheat growth at high $\mathrm{N}$ fertilization in these fields, with associated negative effects on root growth and photosynthesis (Cakmak and Yazici 2010). Alternatively, $\mathrm{Mg}$ requirements are decreasing at increasing $\mathrm{N}$ fertilization, as optimum ratios may not be constant but depend on the plant growth rate or nutrient supply 

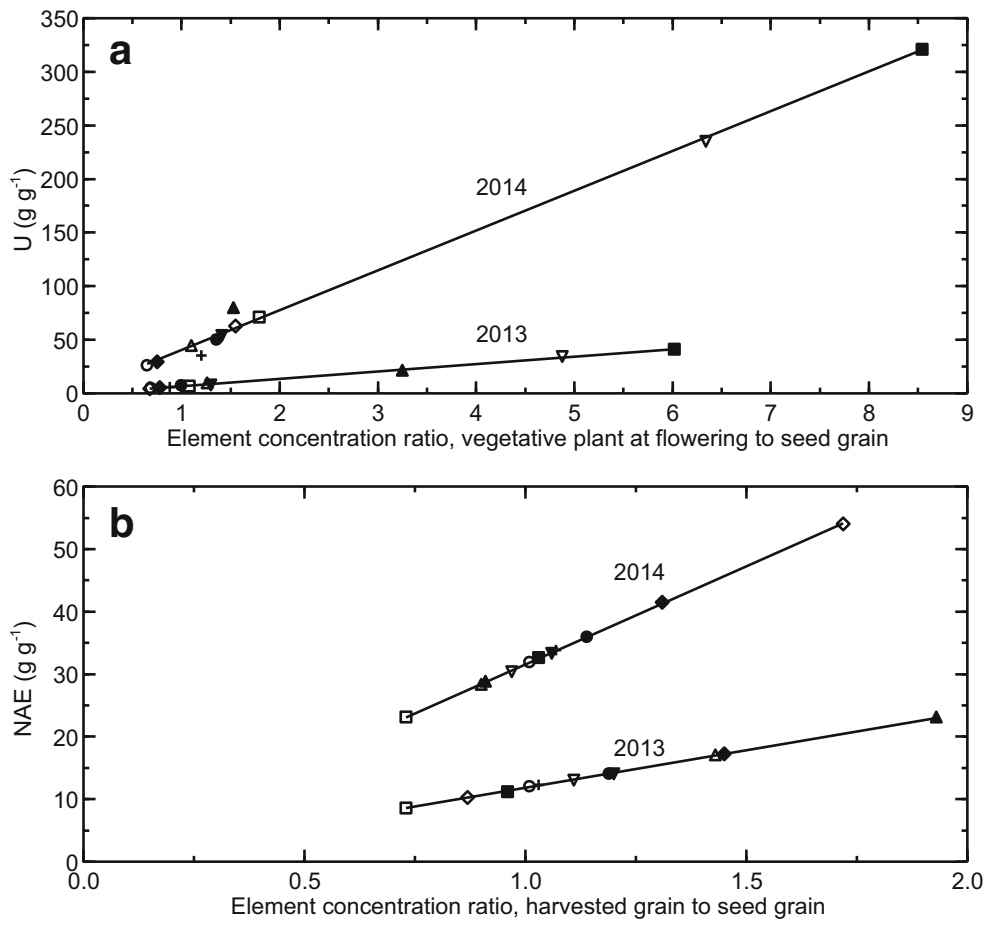

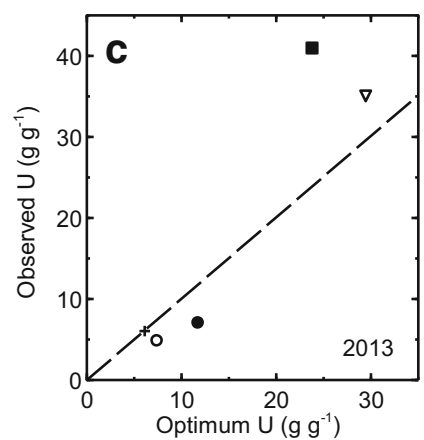

Fig. 4 Relationships among plant-level indices of nutrient accumulation efficiency and element concentration ratios in winter wheat field-grown in monoculture in Central Sweden during two growing seasons (2013 and 2014). a Relationship between the uptake efficiency $(U)$ and element concentration ratios (means in vegetative above-ground biomass at the flowering stage divided by seed grain) for 11 nutrient elements. b Relationship between the nutrient accumulation efficiency (NAE) and element concentration ratios (means in harvested grain by seed grain) for 11 elements. c and $\mathbf{d}$ Relationships between the observed and optimal uptake

rate (Knecht and Goransson 2004). The exact formulation of growth co-limitation by different nutrients appears to be species-specific (Agren 1988) and is a neglected research area (Reich et al. 2014). Future studies should include experiments in which plants grown at different growth rates are limited by several nutrients

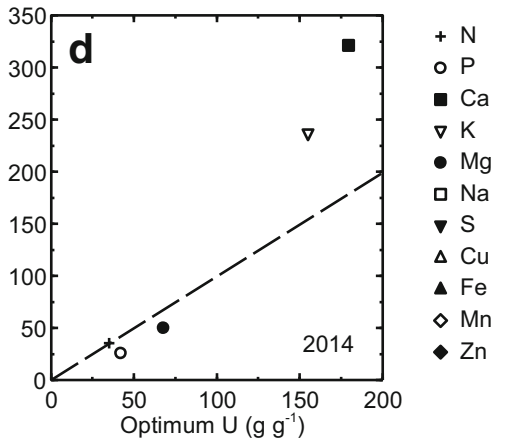

efficiencies $(U)$ for $\mathrm{N}, \mathrm{P}, \mathrm{Ca}, \mathrm{K}$ and $\mathrm{Mg}$; the thresholds for optimal element uptake efficiencies were calculated based on the suggested optimum nutrient ratios for herbaceous plants by Knecht and Goransson (2004). Lines indicate linear regression lines (a, b) or the lines at which observed $U$ equals optimum $U$ values $(\mathbf{c}, \mathbf{d})$. Linear regressions: $y=6.9 * x-0.134$ for 2013 , and $y=37.2 * x+$ 3.19 for 2014 (a); $\mathrm{y}=12.0 * \mathrm{x}-0.180$ for 2013 , and $\mathrm{y}=31.4 * \mathrm{x}+$ 0.189 for 2014 (b); $p<0.001$ in all cases. Data source and detailed information about the growth conditions: Weih et al. (2016)

simultaneously and monitored throughout their entire growth cycles. In this context, the calculation of observed vs. optimum nutrient uptake efficiencies considering the entire growth cycle of agricultural crops, as proposed here, may be a promising tool. In addition, the element ratios by Weih et al. (2011) have 


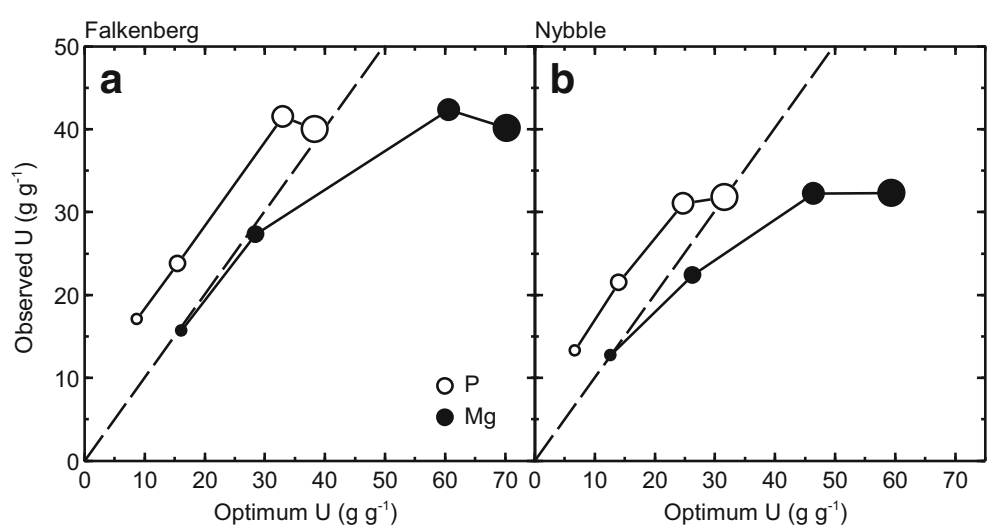

Fig. 5 Plant-level observed and optimum uptake efficiencies $(U)$ for $\mathrm{P}$ and $\mathrm{Mg}$ in winter wheat (cultivar 'Ellvis') grown at four $\mathrm{N}$ fertilizer levels (with addition of P, K and S) during the 2014 growing season at two locations in Central Sweden (a, Falkenberg and $\mathbf{b}$, Nybble near Örebro). The broken lines indicate where the observed $U$ equals optimum $U$ values. Increasing symbol sizes indicate increasing $\mathrm{N}$ fertilizer levels, from 0 to 80,160 and $240 \mathrm{~kg} \mathrm{~N} \mathrm{ha}{ }^{-1}$. The thresholds for optimum $\mathrm{P}$ and $\mathrm{Mg}$ uptake

well-defined system boundaries and thereby facilitate linking the plant-based uptake characteristics for several nutrient elements to the corresponding soil-based ratios for the same elements, and ultimately the up-scaling of nutrient uptake characteristics at whole-plant or field scale to the risks for nutrient leaching at landscape scale (Tidaker et al. 2016).

\section{Conclusions}

There is considerable confusion in the literature regarding the definition and use of nutrient (mostly $\mathrm{N}$ ) use efficiency and its components, and the co-limitation of growth by nutrients other than $\mathrm{N}$ is usually not considered. This study is first in conceptually and quantitatively comparing the indices of a plant-level, a plant-soil-level and a field-level (difference) method for the assessment of $\mathrm{N}$ uptake and use across a set of different annual and perennial crops including wheat (grain), maize (feed), potato (starch), grassland ley (feed) and Salix (bio-energy) fieldgrown in Sweden. The six different crops are characterized in terms of some important $\mathrm{N}$ uptake and utilization aspects by using a set of five plant-level indices. Also a methodology for exploring the co-limitation of growth by nutrients other than $\mathrm{N}$ is proposed.

When comparing the plant-level and plant-soil-level methods, the indices relating crop yields to the amounts of plant-internal $\mathrm{N}$ were correlated, while the $\mathrm{N}$-uptake efficiencies were calculated based on the suggested optimum $\mathrm{N}: \mathrm{P}: \mathrm{Mg}$ ratios of 100:14.3:8.7 for herbaceous plants by Knecht and Goransson (2004). In the (seed) grain, the N:P:Mg ratio was $100: 22.2: 7.4$. Each data point is calculated by dividing the mean from four seed grain replicates by the mean from four replicates sampled at crop flowering, a procedure not allowing the calculation of simple variability measures. Data source and detailed information about the growth conditions: Hamner et al. (2017)

indices were not. Only few of the field-level (difference method) indices were correlated with indices of the plant-level and plant-soil-level methods.

The plant-soil-level indices work well for comparisons of nutrient uptake and utilization among functionally similar annual plants or crops when applied in agricultural contexts, especially for the evaluation of recovery efficiencies in the sense of plant-internal nutrient uptake per unit of soil-available nutrient amount. Major limitations are that these indices are usually restricted to annual plants, do not consider all plantinternal nutrient inputs (e.g. from seeds or other perennial plant parts), and frequently have unclear system boundaries.

The plant-level indices have well-defined system boundaries and can be adapted for the integrated evaluation of the nutrient accumulation and utilization characteristics of both annual and perennial plants. Major limitations include the impossibility of obtaining measures of nutrient recovery efficiencies from soil (if not additional assessments of soil nutrient supply are carried out), and the requirement of accurate estimates of mean nutrient amounts during the growth period, which might be difficult to achieve especially in fast-growing plants.

Some of the plant-level indices used here allow the exploration of the co-limitation of growth by nutrients other than N. The proposed methodology is relevant for future research on the co-limitation of growth and its dependency on species and environmental factors. 
Open Access This article is distributed under the terms of the Creative Commons Attribution 4.0 International License (http:// creativecommons.org/licenses/by/4.0/), which permits unrestricted use, distribution, and reproduction in any medium, provided you give appropriate credit to the original author(s) and the source, provide a link to the Creative Commons license, and indicate if changes were made.

\section{References}

Agren GI (1985) Theory for growth of plants derived from the nitrogen productivity concept. Physiol Plant 64:17-28

Agren GI (1988) Ideal nutrient productivities and nutrient proportions in plant growth. Plant Cell Environ 11:613-620

Asplund L, Bergkvist G, Weih M (2014) Proof of concept: nitrogen use efficiency of contrasting spring wheat varieties grown in greenhouse and field. Plant Soil 374:829-842

Asplund L, Bergkvist G, Weih M (2016) Functional traits associated with nitrogen use efficiency in wheat. Acta Agric Scand Sect B-Soil Plant Sci 66:153-169

Barbieri PA, Echeverria HE, Sainz Rozas HR, Andrade FH (2008) Nitrogen use efficiency in maize as affected by nitrogen availability and row spacing. Agron J 100:1094-1100. https://doi.org/10.2134/agronj2006.0057

Barraclough PB, Howarth JR, Jones J, Lopez-Bellido R, Parmar S, Shepherd CE, Hawkesford MJ (2010) Nitrogen efficiency of wheat: genotypic and environmental variation and prospects for improvement. Eur J Agron 33:1-11. https://doi. org/10.1016/j.eja.2010.01.005.

Bulisani EA, Warner RL (1980) Seed protein and nitrogen effects upon seedling vigor in wheat. Agron J 72:657-662

Burns IG (2006) Assessing $N$ fertiliser requirements and the reliability of different recommendation systems. In: Tei F, Benincasa P, Guiducci M (eds) Proceedings of the international symposium towards ecologically sound fertilisation strategies for field vegetable production. Acta Horticulturae, vol 700, pp 35-48

Cakmak I, Yazici AM (2010) Magnesium: a forgotten element in crop production. Better Crops with Plant Food 94:23-25

Carlsson G, Huss-Danell K (2003) Nitrogen fixation in perennial forage legumes in the field. Plant Soil 253:353-372. https://doi.org/10.1023/a:1024847017371.

Carter M, Gregorich E (2008) Soil sampling methods of analysis. Taylor \& Francis, Boca Raton

Dobermann AR (2005) Nitrogen use efficiency - state of the art. Agronomy \& Horticulture Faculty Publications 316. http://digitalcommons.unl.edu/agronomyfacpub/316. Accessed 3 July 2018

Drenovsky RE, Richards JH (2004) Critical N : P values: predicting nutrient deficiencies in desert shrublands. Plant Soil 259:59-69

Elser JJ, Fagan WF, Kerkhoff AJ, Swenson NG, Enquist BJ (2010) Biological stoichiometry of plant production: metabolism, scaling and ecological response to global change. New Phytol 186:593-608

Evans LE, Bhatt GM (1977) Influence of seed size, protein content and cultivar on early seedling vigor in wheat. Can J Plant Sci 57:929-935
Fageria NK, Baligar VC (2005) Enhancing nitrogen use efficiency in crop plants. Adv Agron 88:97-185

Fageria NK, Baligar VC, Li YC (2008) The role of nutrient efficient plants in improving crop yields in the twenty first century. J Plant Nutr 31:1121-1157

Gauer LE, Grant CA, Gehl DT, Bailey LD (1992) Effects of nitrogen fertilization on grain protein content, nitrogen uptake, and nitrogen use efficiency of six spring wheat (Triticum aestivum L.) cultivars, in relation to estimated moisture supply. Can J Plant Sci 72:235-241

Good AG, Shrawat AK, Muench DG (2004) Can less yield more? Is reducing nutrient input into the environment compatible with maintaining crop production? Trends Plant Sci 9:597605

Hamner K, Weih M, Eriksson J, Kirchmann H (2017) Influence of nitrogen supply on macro- and micronutrient accumulation during growth of winter wheat. Field Crop Res 213:118-129. https://doi.org/10.1016/j.fcr.2017.08.002

Hanley ME, Cordier PK, May O, Kelly CK (2007) Seed size and seedling growth: differential response of Australian and British Fabaceae to nutrient limitation. New Phytol 174: 381-388. https://doi.org/10.1111/j.1469-8137.2007.02003.x

Hirose T (2011) Nitrogen use efficiency revisited. Oecologia 166: 863-867. https://doi.org/10.1007/s00442-011-1942-z

Knecht MR, Goransson A (2004) Terrestrial plants require nutrients in similar proportions. Tree Physiol 24:447-460

Koerselman W, Meuleman AFM (1996) The vegetation N:P ratio: a new tool to detect the nature of nutrient limitation. J Appl Ecol 33:1441-1450. https://doi.org/10.2307/2404783

Leip A, Britz W, Weiss F, de Vries W (2011) Farm, land, and soil nitrogen budgets for agriculture in Europe calculated with CAPRI. Environ Pollut 159:3243-3253. https://doi. org/10.1016/j.envpol.2011.01.040

Manschadi AM, Kaul H-P, Vollmann J, Eitzinger J, Wenzel W (2014) Developing phosphorus-efficient crop varieties-an interdisciplinary research framework. Field Crop Res 162: 87-98. https://doi.org/10.1016/j.fcr.2013.12.016

Moll RH, Kamprath EJ, Jackson WA (1982) Analysis and interpretation of factors which contribute to efficiency of nitrogen utilization. Agron J 74:562-564

Naegle ER, Burton JW, Carter TE, Rufty TW (2005) Influence of seed nitrogen content on seedling growth and recovery from nitrogen stress. Plant Soil 271:329-340

Norton RD, E., Roberts, T. (2015) Nitrogen use efficiency and nutrient performance indicators. Global Partnership on Nutrient Management Task Team Workshop, Washington DC, pp 1-14.

Oenema O, Kros H, de Vries W (2003) Approaches and uncertainties in nutrient budgets: implications for nutrient management and environmental policies. Eur J Agron 20:3-16. https://doi.org/10.1016/s1161-0301(03)00067-4

Osterholz WR, Rinot O, Liebman M, Castellano MJ (2017) Can mineralization of soil organic nitrogen meet maize nitrogen demand? Plant Soil 415:73-84. https://doi.org/10.1007 /s11104-016-3137-1

Pourazari F (2016) Nutrient economy in annual and perennial crops. Department of Crop Production Ecology. In: Dissertation, Swedish University of Agricultural Sciences, vol 70. Acta Universitatis Agriculturae Sueciae 2016, Uppsala, Sweden 
Pourazari F, Andersson M, Weih M (2018) Altered tuber yield in genetically modified high-amylose and oil potato lines is associated with changed whole-plant nitrogen economy. Front Plant Sci 9. https://doi.org/10.3389/fpls.2018.00342

Reich M, Aghajanzadeh T, De Kok LJ (2014) Physiological Basis of Plant Nutrient Use Efficiency - Concepts, Opportunities and Challenges for Its Improvement. In: Hawkesford MJ, Kopriva S, DeKok LJ (eds) Nutrient Use Efficiency in Plants: Concepts and Approaches, pp 1-27

Rose TJ, Mori A, Julia CC, Wissuwa M (2016) Screening for internal phosphorus utilisation efficiency: comparison of genotypes at equal shoot $\mathrm{P}$ content is critical. Plant Soil 401:7991. https://doi.org/10.1007/s11104-015-2565-7

Santa-Maria GE, Moriconi JI, Oliferuk S (2015) Internal efficiency of nutrient utilization: what is it and how to measure it during vegetative plant growth? J Exp Bot 66:3011-3018. https://doi.org/10.1093/jxb/erv162

Spiertz JHJ, Ewert F (2009) Crop production and resource use to meet the growing demand for food, feed and fuel: opportunities and constraints. Njas-Wageningen Journal of Life Sciences 56:281-300

Tidaker P, Bergkvist G, Bolinder M, Eckersten H, Johnsson H, Katterer T, Weih M (2016) Estimating the environmental footprint of barley with improved nitrogen uptake efficiency-a Swedish scenario study. Eur J Agron 80:45-54

Tilman D, Cassman KG, Matson PA, Naylor R, Polasky S (2002) Agricultural sustainability and intensive production practices. Nature 418:671-677. https://doi.org/10.1038/nature01014 van Bueren ETL, Thorup-Kristensen K, Leifert C, Cooper JM, Becker HC (2014) Breeding for nitrogen efficiency: concepts, methods, and case studies. Euphytica 199(1-2):1-2. https://doi.org/10.1007/s10681-014-1206-1

Weih M, Nordh NE (2005) Determinants of biomass production in hybrid willows and prediction of field performance from pot studies. Tree Physiol 25:1197-1206

Weih M, Asplund L, Bergkvist G (2011) Assessment of nutrient use in annual and perennial crops: a functional concept for analyzing nitrogen use efficiency. Plant Soil 339:513-520

Weih M, Pourazari F, Vico G (2016) Nutrient stoichiometry in winter wheat: element concentration pattern reflects developmental stage and weather. Sci Rep 6:35958-35958

Weih M, Westerbergh A, Lundquist PO (2017) Role of nutrientefficient plants for improving crop yields: bridging plant ecology, physiology, and molecular biology. In: Hossain MA, Kamiya T, Burritt DJ, Tran LSP, Fujiwara T (eds) Plant Macronutrient Use Efficiency: Molecular and Genomic Perspectives in Crop Plants. Academic Press LtdElsevier Science Ltd, London, pp 31-44

Xu G, Fan X, Miller AJ, SM B, DZ H (2012) Plant nitrogen assimilation and use efficiency: The importance of cytosolic glutamine synthetase in nitrogen assimilation and recycling. Annu Rev Plant Biol 63: 153-182. https://doi.org/10.1146 /annurev-arplant-042811-105532.

Zebarth BJ, Tai G, Tarn R, de Jong H, Milburn PH (2004) Nitrogen use efficiency characteristics of commercial potato cultivars. Can J Plant Sci 84:589-598 